\title{
Expression of Human GLI in Mice Results in Failure to Thrive, Early Death, and Patchy Hirschsprung-like Gastrointestinal Dilatation
}

\author{
Jian Tao Yang, Cheng Zheng Liu, Elisabeth H. Villavicencio, \\ Joon Won Yoon, David Walterhouse, and Philip M. Iannaccone \\ Department of Pediatrics and Children's Memorial Institute for \\ Education and Research, Northwestern University Medical School, \\ Chicago, Illinois, U.S.A.
}

\begin{abstract}
Background: $G L I$ is an oncodevelopmental gene in the vertebrate hedgehog/patched signaling pathway that is spatiotemporally regulated during development and is amplified in a subset of human cancers. GLI is the prototype for the Gli-Kruppel family of transcription factors, which includes the Drosophila segment polarity gene $c i$, the $C$. elegans sex-determining gene tra-1, and human and mouse GLI3, all of which contain a conserved domain of five $\mathrm{C}_{2}-\mathrm{H}_{2}$ zinc fingers. GLI3 mutations have been implicated in the mouse mutant extra toes, as well as in human Greig cephalopolydactaly syndrome and the autosomal dominant form of Pallister-Hall syndrome. As such, GLI and the vertebrate hedgehog/patched signaling pathway appear to play important roles in both normal development and neoplasia.

Materials and Methods: Since it is not known whether aberrant $G L I$ expression is similarly linked to developmental disorders, we developed gain-of-function transgenic mice which express human GLI ectopically.
\end{abstract}

Results: Affected transgenic mice exhibit a phenotype of failure to thrive, early death, and Hirschsprung-like patches of gastrointestinal dilatation. The colons of affected mice have greatly attenuated smooth muscle layers and abnormal overlying epithelium. The density of myenteric plexuses is reduced in the colonic walls. The severity of the phenotype is related to the level of transgene expression.

Conclusions: The transgenic mouse model supports a role for $G L I$ in gastrointestinal development. As part of the vertebrate hedgehog/patched signaling pathway, GLI is essential to mesoderm and CNS ectoderm development and transgenic GLI expression affects neuronal, muscular, and epithelial cell differentiation in the gut. Expression of human GLI in mice results in impairment of enteric neuronal development and a Hirschsprung-like phenotype.

\section{INTRODUCTION}

$G L I$ is the prototypical gene of the Gli-Kruppel family of transcription factors and is a mediator of hedgehog/patched signaling (1-4). The pathway is highly conserved, with homologous genes present in C. elegans, Drosophila, chick, mouse,

Address correspondence and reprint requests to: Dr. P.M. Iannaccone, Department of Pediatrics, Northwestern University Medical School, Children's Memorial Institute for Education and Research, 2300 Children's Plaza (MC 204), Chicago, IL 60614, U.S.A. Tel: 773-880-8236; Fax: 773-

880-8266; E-mail: pmi@nwu.edu and human (5-7). The vertebrate hedgehog/ patched signaling pathway has been shown to be essential for normal development $(8,9)$. Mutations of the genes Sonic Hedgehog, Patched, and GLI3 cause the human disorders holoprosencephaly (10), basal cell nevus syndrome (1), and Greig cephalopolydactyly syndrome (12) and Pallister-Hall syndrome (13-15), respectively. In vertebrates there are three GLI genes based on sequence homology in the region coding for the zinc finger DNA binding domains; GLI, GLI2, and GLI3. The human GLI gene has not yet been 
linked to a known developmental disorder, but its amplification in some gliomas, osetosarcomas, and rhabdomyosarcomas suggests an important role in growth regulation (16).

The human GLI gene is expressed in the human embryonal carcinoma cell lines Tera-1 and NTera-2 but not in normal adult tissues, except for very low levels in testes, myometrium, cerebellum, and oviduct $(3,17)$. To localize the expression of mouse gli during development, in situ hybridization studies were performed on wild-type mouse embryos. In E7.5 mouse embryos, gli transcripts were present in ectoderm and mesoderm, but not in endoderm. In E10 through E18 embryos, gli transcripts were present in the primordia of the central nervous system, skeletal system, and the gastrointestinal (GI) tract. Expression was evident in the mesoderm of developing GI tract, Meckel's precartilage mesenchyme, the basis occipitus, rib mesenchymal condensations, primordial vertebral bodies, digital mesenchymal condensations in forefoot and hindfoot plates, the ependymal layer of the spinal cord, most anterior and ventral parts of the telencephalon, several regions of the ventral mesencephalon, and the developing choroid plexus $(8,9)$.

Here we report the production of transgenic mice which express human GLI. The transgenic animals display a complex phenotype related to the level of transgene expression, which includes abnormal development of the colon and patchy Hirschsprung-like dilatation. The colonic defect is associated with abnormal epithelium and decreased density of myenteric plexuses.

\section{MATERIALS AND METHODS}

\section{Transgenic Mice}

To generate gain-of-function mice, full-length human GLI cDNA was ligated to the inducible 770 bp mouse metallothionein-1 (pMT-1) promoter. An SV40 small t intron was inserted between pMT-1 and GLI, and the plasmid was cut with BssHII to yield a $4.7 \mathrm{~kb}$ fusion gene for microinjection. We then microinjected $2 \mu \mathrm{g} / \mu \mathrm{l}$ DNA into the pronucleus of one-cell ICR mouse embryos, which were transferred to pseudopregnant CB6Fl surrogate mothers. Southern blot analysis of mouse tail DNA identified one male founder, which was bred to a wild-type ICR female. The GLI transgene showed Mendelian transmission, and hemizygous Fl siblings
$(G L I /+)$ were mated to produce homozygous transgenic mice (GLI/GLI), which were identified by Southern blot analysis. Homozygosity was confirmed by analysis of the test-cross offspring.

\section{DNA Isolation}

One-half centimeter of mouse tail was incubated in $1 \mathrm{ml}$ lysis buffer ( $50 \mathrm{mM}$ Tris, $\mathrm{pH} 9.0,50 \mathrm{mM}$ EDTA, $0.4 \mathrm{M} \mathrm{NaCl}, 5 \mathrm{mM}$ DTT, $2.5 \mathrm{mM}$ Spermidine, $1 \%$ SDS, $1 \mathrm{mg} / \mathrm{ml}$ fresh Proteinase $\mathrm{K}$ ) at $55^{\circ} \mathrm{C}$ overnight. The supernatant was mixed with $5 \mathrm{ml}$ lysis buffer B ( $50 \mathrm{mM}$ Tris, $\mathrm{pH} 8.0,50$ mM EDTA, $400 \mathrm{mM} \mathrm{NaCl}$ ) and $2 \mathrm{ml}$ saturated $\mathrm{NaCl}$. After centrifuging, $5 \mathrm{ml}$ isopropanol was added to the supernatant and mixed by swirling. The DNA was redissolved in TE.

\section{RNA Isolation}

Total RNA or poly (A) ${ }^{+}$RNA were isolated with Qiagen RNeasy ${ }^{\mathrm{TM}}$ or Oligotex ${ }^{\mathrm{TM}}$ mRNA kits, respectively. For reverse transcription-polymerase chain reaction (RT-PCR), total RNA was treated with RNase-free DNase, which was removed from the RNA samples with RNeasy ${ }^{\mathrm{TM}}$ columns.

\section{Southern Hybridization Analysis}

Five micrograms of genomic DNA from each mouse was digested with BamHI and $\mathrm{XbaI}$ and electrophoresed on $0.8 \%$ agarose gels, then transferred to Bio-Rad Zeta-probe membranes in $0.4 \mathrm{M} \mathrm{NaOH}$ for 2-3 hr. The membranes were air-dried and baked at $80^{\circ} \mathrm{C}$ for $30 \mathrm{~min}$. The probe for Southern analysis was a $2.1 \mathrm{~kb}$ fragment of human GLI cDNA cut with XhoII and was labeled with a random primer labeling kit at $10^{9} \mathrm{cpm} / \mu \mathrm{g}$ specific activity. The membranes were prewet with hybridization solution $(0.5 \mathrm{M}$ $\mathrm{NaH}_{2} \mathrm{PO}_{4}, \mathrm{pH} 7.2$ and 7\% SDS) and hybridized at $65^{\circ} \mathrm{C}$ overnight in $3 \mathrm{ml}$ of hybridization solution; the final probe concentration was $2 \times 10^{6} \mathrm{cpm} /$ $\mathrm{ml}$. After hybridization, the membranes were washed three times at $65^{\circ} \mathrm{C}$ in $20 \mathrm{mM} \mathrm{Na}_{2} \mathrm{HPO}_{4}$, $\mathrm{pH} 7.2,1 \%$ SDS solution.

\section{RT-PCR}

One hundred nanograms of total RNA or $50 \mathrm{ng}$ of poly (A) ${ }^{+}$RNA was treated with RNase-free DNase I (Boehringer Mannheim), and RT-PCR was performed using the GeneAmp RNA PCR kit (Perkin Elmer Cetus). The reverse transcription reaction was performed at room temperature for 
$10 \mathrm{~min}$ for annealing and at $42^{\circ} \mathrm{C}$ for $50 \mathrm{~min}$ for synthesis of CDNA, then at $99^{\circ} \mathrm{C}$ for $5 \mathrm{~min}$, and finally placed on ice until the reaction buffer for PCR amplification was added. Primers and polymerase were added for PCR amplification. The method distinguished between endogenous and transgene expression by using human-specific primers (5'-GACCATGCACTGTCTTGACA-3' and 5'-AGTCATACTCACGCCTCGAA-3') to amplify a $238 \mathrm{bp}$ fragment of the transgene.

\section{Quantitative PCR}

RT-PCR reactions were carried out using five concentrations of RNA. Band intensities were quantified using NIH Image after digital scanning. Linear response ranges were established for both actin and the transgene RT-PCR product. Actin-to-transgene band intensity ratios were established and compared using data points from the 10-ng reactions, which were within the linear ranges of both actin and the transgene.

\section{RESULTS}

\section{Generation of GLI Gain-of-Function Transgenic Mice}

To study GLI expression in vivo, we generated gain-of-function transgenic mice expressing fulllength human GLI cDNA under the control of the inducible mouse metallothionein-1 (pMT-1) promoter; microinjections were performed using standard techniques (18). Homozygosity was confirmed by Southern blot analysis of mouse tail DNA and test cross (Fig. 1). The mice were divided into four groups: wild type, wild type with zinc supplementation $\left(25 \mathrm{mM} \mathrm{ZnSO}_{4}\right.$ in drinking water), transgenic mice, and transgenic mice with zinc supplementation. Zinc treatment to induce transgene expression in treated groups was first administered to pregnant mothers and then to pups throughout life. Zinc treatment had no effect on wild-type mice.

\section{GLI Transgenic Mice Exhibit Failure to Thrive, Premature Death, and Hirschsprung-like Gastrointestinal Dilatation}

Fifty-one percent of the $\mathrm{Zn}^{++}$-induced GLI homozygotes failed to grow normally; on average, they were $40 \%$ smaller than comparably aged control animals (Fig. 2A). It is not known why only some of the induced transgenic animals demonstrated this phenotype. The small mice did continue to grow, and their growth curves remained parallel to those of unaffected mice (Fig. 2B). A few small animals were also noted in the noninduced homozygous group, suggesting leaky induction of $G L I$ transgene expression. Interestingly, the females were twice as likely to demonstrate the undersized phenotype (Fig. 2C). Several of the small males were noted to have priapism. In addition to inhibited growth, many of the homozygous mice died prematurely. Of the zinc treated transgenic animals, 35.2\% died between 1 and 4 days after birth; additional zinctreated mice died at 3 to 4 weeks of age, and a significant number of transgenic animals with or without zinc treatment died between 3 and 6 months of age. Within 6 months, $60.3 \%$ of the zinc-induced animals and $25.5 \%$ of the nonzinc-induced homozygotes died. In contrast, none of the wild-type mice died during this period (Fig. 2D).

GLI is normally expressed during the development of gastrointestinal mesoderm, so it was hypothesized that normal GI tract development might be affected in GLI transgenic mice. The transgenic mice showed histologic and gross intestinal abnormalities. Seven of 13 dissected homozygous mice displayed a Hirschsprung-like phenotype of patchy dilatation of the intestinal wall from the ileum to the colon (Fig. 3A, E, F). Hematoxylin and eosin-stained tissue showed that the smooth muscle layer of the gastrointestinal wall was attenuated and the number of myenteric plexuses was greatly reduced in affected regions (Table 1); neuron-specific enolase (NSE) stains confirmed that plexuses were virtually absent from the affected areas (Fig. 3B). Some NSE-positive material suggested the presence of preganglionic fibers in affected areas of colonic wall. In unaffected regions of the same specimens, myenteric plexuses were present, but at a reduced number compared with control colon. In regions of attenuated smooth muscle the overlying colonic epithelium was distinctly abnormal, with greatly decreased overall thickness and relative absence of goblet cells. The attenuated epithelium was low cuboidal and arrayed in small pseudovilli (Fig. 3A, B). Complete epithelial development has been shown to require correct signaling from underlying mesodermal elements (19-22). It is possible that dysregulated GLI expression in the mesoderm of the developing GI tract results directly both in improper smooth muscle development and functionally 


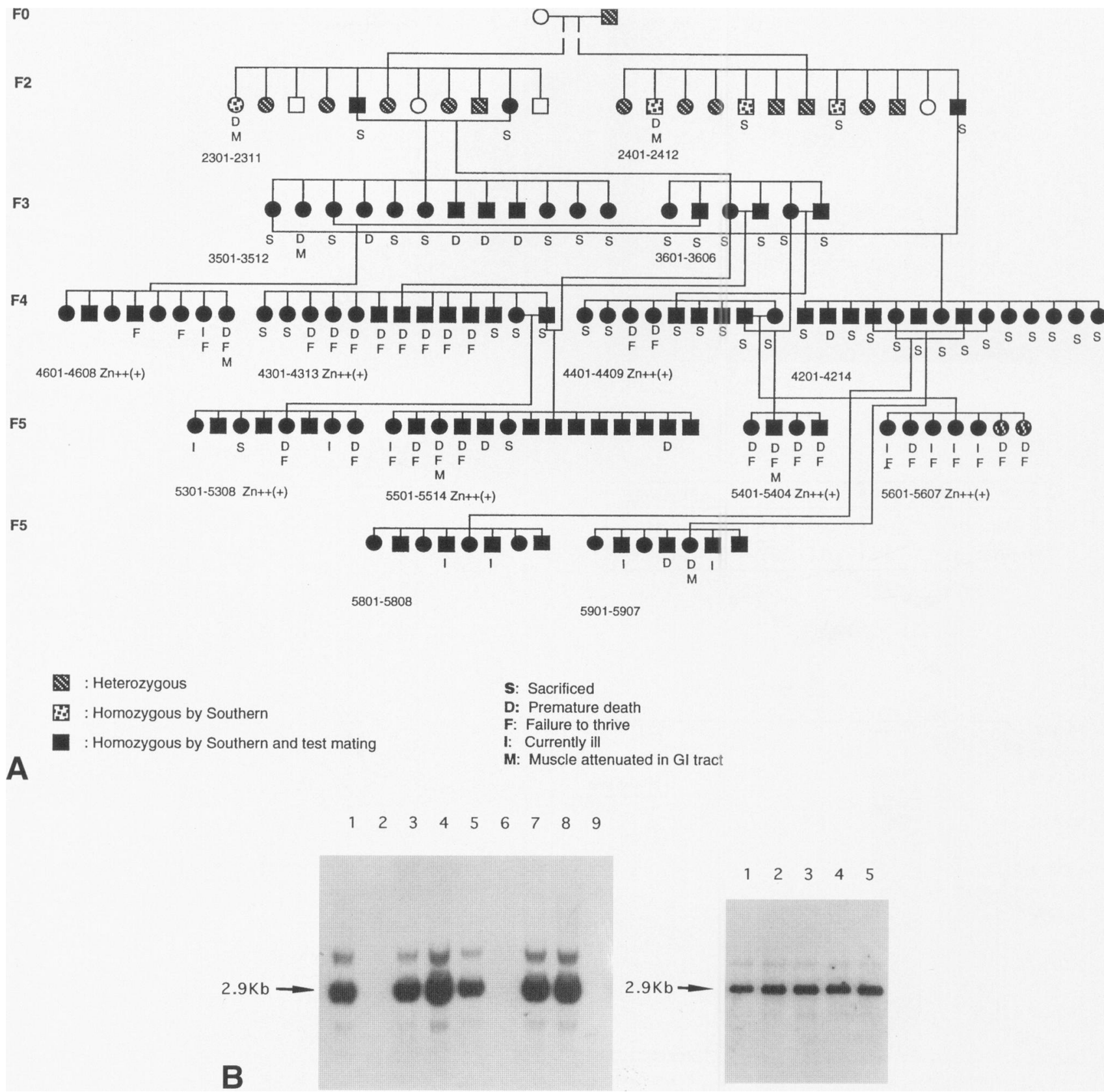

\section{FIG. 1. GLI transgenic mice}

The transgene construct comprised full-length human GLI under the control of the $770 \mathrm{bp}$ mouse metallothionein (pMT-1) promoter, separated by the SV40 small $\mathrm{t}$ intron. The $4.7 \mathrm{~kb}$ fusion gene was released from the plasmid by BssHII digestion and was microinjected into the pronuclei of fertilized mouse eggs. (A) Pedigree of the GLI transgenic mice. The four-digit designation for each mouse denotes the generation, litter number, and specific animal. (B, left) Fl litter Southern hybridization analysis: for each animal, $5 \mu \mathrm{g}$ mouse tail genomic DNA was digested with BamHI and $X b a I$, then hybridized under stringent conditions with a $2.1 \mathrm{~kb}$ XhoII-digested human GLI cDNA probe. Lanes 1, 3, 4, 5, 7, and 8 are transgenic animals; lanes 2, 6, and 9 are nontransgenic litter mates. The arrow indicates the predicted $2.9 \mathrm{~kb}$ band. (B, right) Southern blot analysis of homozygous transgenic mice resulting from hemizygous Fl mating. Lane 1 is an Fl hemizygous transgenic animal; lanes $2-5$ were presumed to be homozygous transgenic animals because of their double-intensity hybridization signals. This was subsequently proved by breeding. 
A

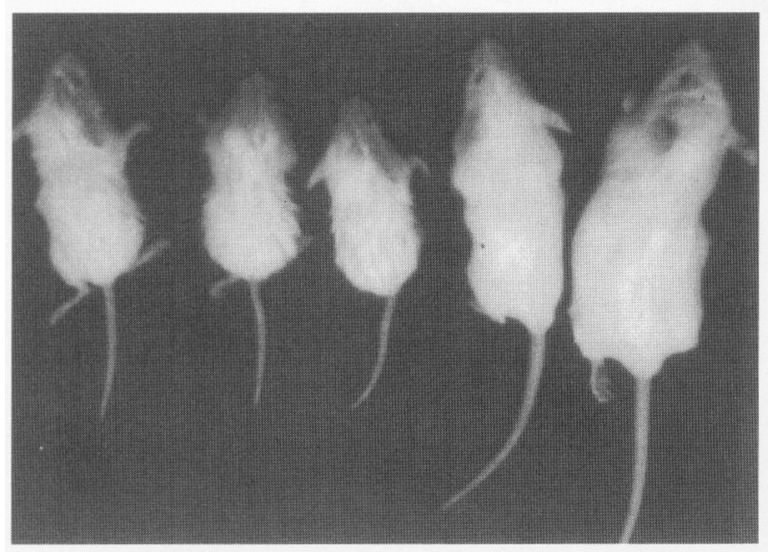

C

\begin{tabular}{|l|cc|cc|cc|}
\hline SIZE & \multicolumn{2}{|c|}{ MALE } & \multicolumn{2}{c|}{ FEMALE } & \multicolumn{2}{c|}{ AVERAGE } \\
\hline Small & $5 / 18$ & $28 \%$ & $14 / 21$ & $67 \%$ & $21 / 41$ & $51.2 \%$ \\
Normal & $13 / 18$ & $72 \%$ & $7 / 21$ & $33 \%$ & $20 / 41$ & $48.8 \%$ \\
\hline
\end{tabular}

D

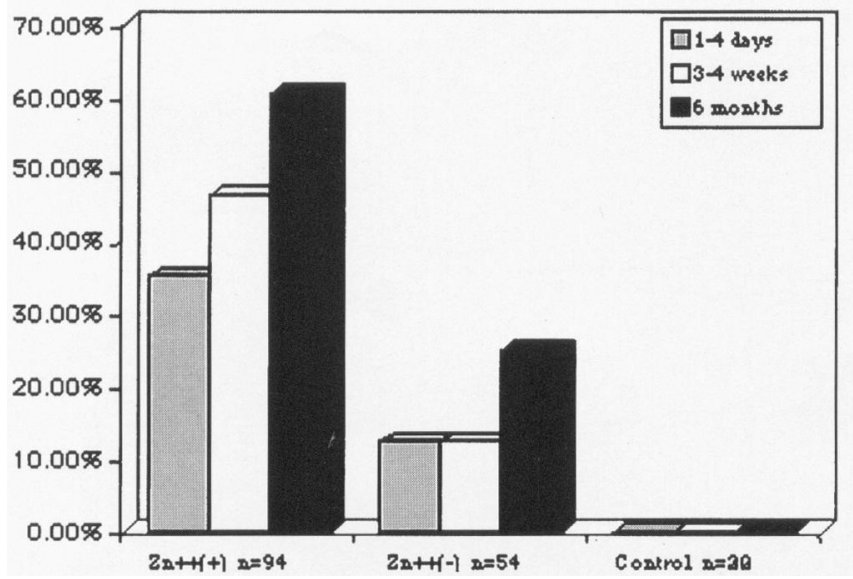

B

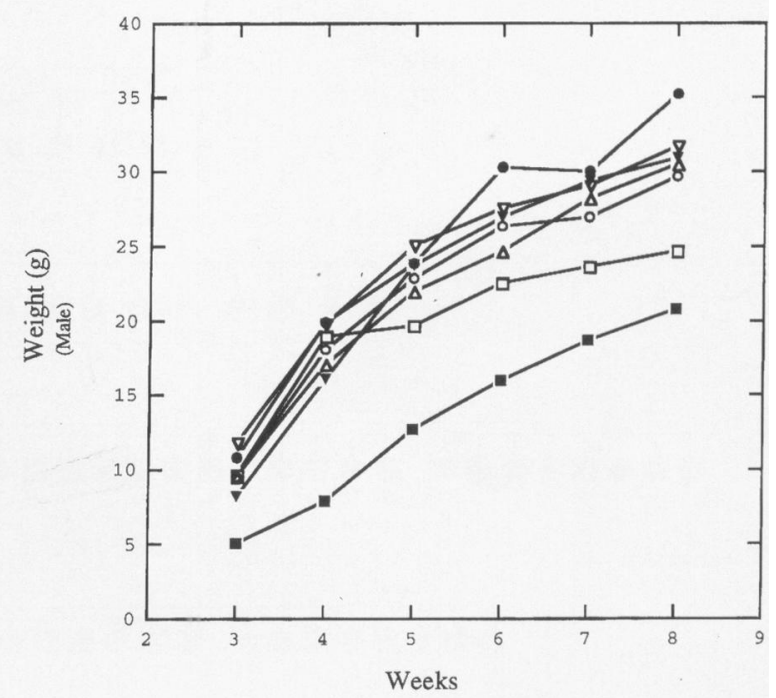

क्री

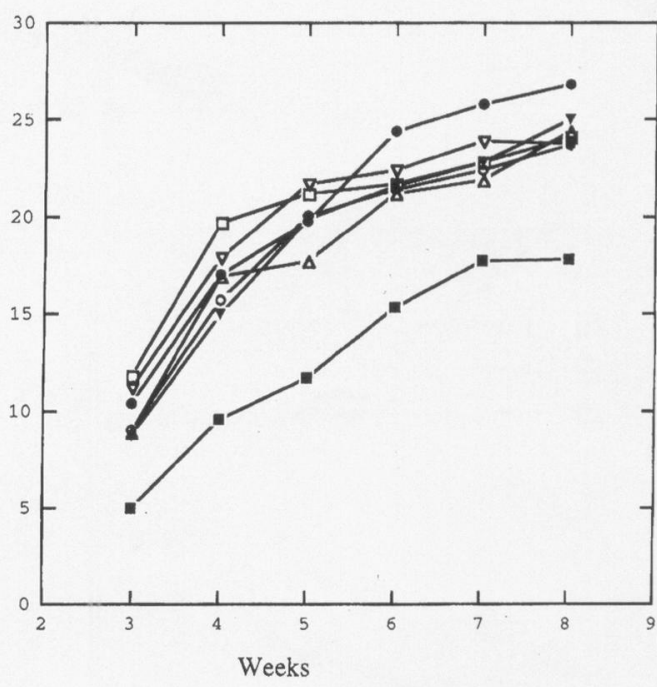

- Wild type $\mathrm{Zn++}$ noninduced

- Wild type $\mathrm{Zn}++$ induced

$\nabla$ Heterozygous $\mathrm{Zn++}$ noninduced

- Heterozygous $\mathrm{Zn++}$ induced

․ Homozygous $\mathrm{Zn++}$ noninduced

- Homozygous small size animals $\mathrm{Zn}++$ induced

$\Delta$ Homozygous normal size animals $\mathrm{Zn}++$ induced

\section{FIG. 2. Failure to thrive and premature death in homozygous $G L I$ transgenic mice}

(A) Four-week old mice, from right to left: normal wild-type CD-1 mouse, homozygous noninduced transgenic mouse, three $\mathrm{Zn}^{++}$-induced homozygous transgenic mice. (B) Growth curves of male (top) and female (bottom) mice illustrate failure to thrive in a subset of $\mathrm{Zn}^{++}$-induced homozygous transgenic animals. Growth of small animals remains parallel to the growth of unaffected animals. Points represent mean values. $\mathrm{O}$ : wild-type $\mathrm{Zn}^{++}-\mathrm{non}^{-}$ induced, $n=17$ females, 24 males; 0 : wild-type $\mathrm{Zn}^{++}$-induced, $n=12$ females, 9 males; $\nabla:$ heterozygous $\mathrm{Zn}^{++}$noninduced, $n=16$ females, 6 males; $\nabla$ : heterozygous $\mathrm{Zn}^{++}$-induced, $n=11$ females, 11 males; $\square$ : homozygous $\mathrm{Zn}^{++}$-noninduced, $n=7$ females, 7 males; $\mathbf{0}$ : homozygous small-sized animals $\mathrm{Zn}^{++}$-induced, $n=14$ females, 5 males; $\triangle$ : homozygous normal sized animals $\mathrm{Zn}^{++}$-induced, $n=9$ females, 13 males. There is no significant difference between wild type $\mathrm{Zn}^{++}$-induced and the other groups except homozygous GLI transgenic small-sized animals $\mathrm{Zn}^{++}$-induced. $P<.05$ for both male and female (t-test). (C) Failure to thrive was defined as weight smaller than 2 SD below wild-type weight. The phenotype was more prevalent in females than in males. $P<.03$ (Fisher's exact test). (D) Cumulative premature death in homozygous $G L I$ transgenic mice. $\mathrm{Zn}^{++}(+)$: homozygous transgenic mice fed $25 \mathrm{mM} \mathrm{ZnSO}$ in drinking water since conception; $\mathrm{Zn}^{++}(-)$: homozygous transgenic mice without supplemental zinc; control group: wild-type animals with $\mathrm{Zn}^{++}$-induction. The $\mathrm{y}$-axis is cumulative mortality in percentage. 

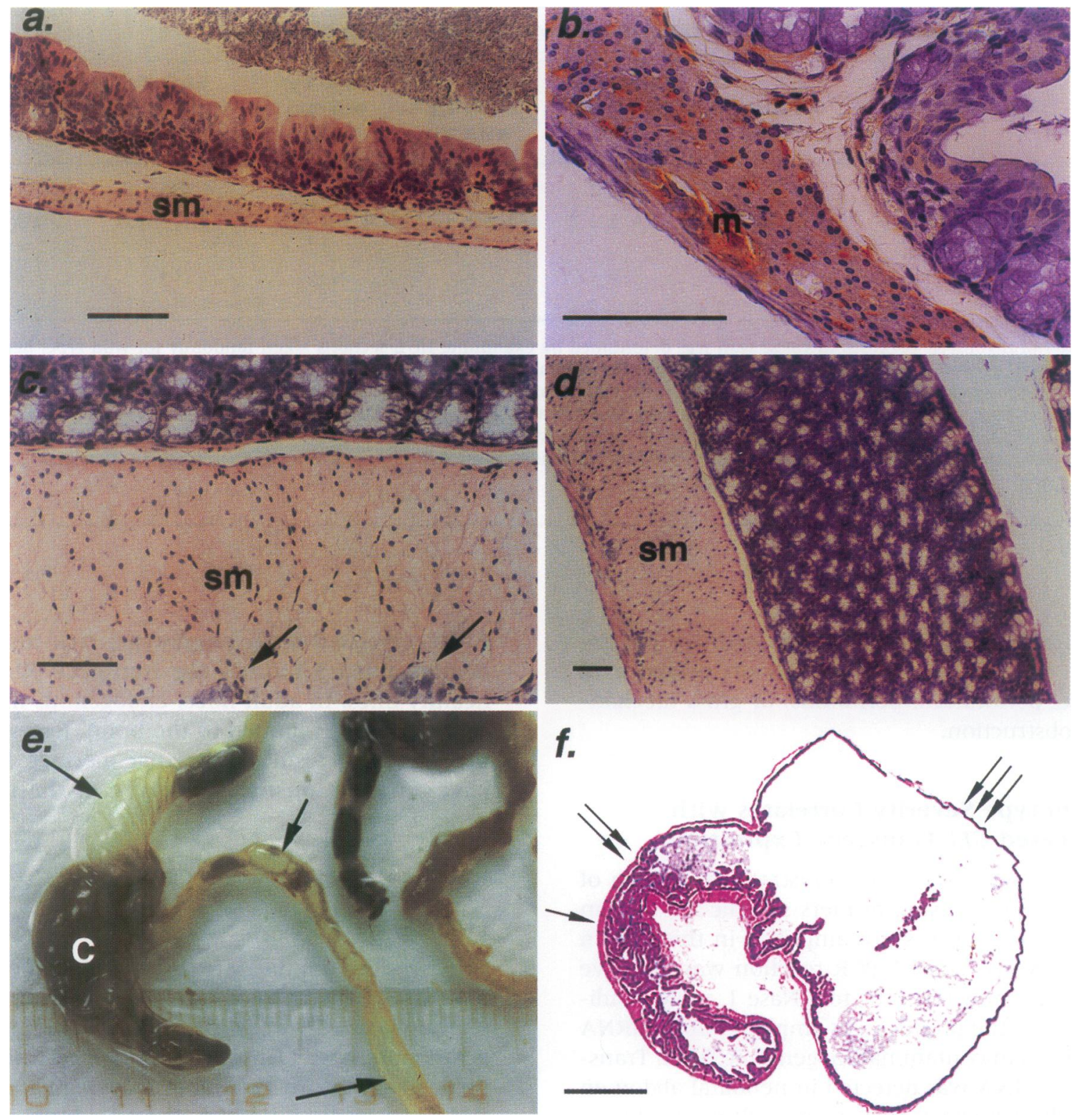

FIG. 3. Gastrointestinal phenotype in GLI transgenic mice

(A) Attenuation of smooth muscle (sm) in colon of homozygous transgenic mouse 2402. (B) Neuron-specific enolase (NSE) shows normal myenteric plexuses (brown-stained structures, $m$ ) in the unaffected musculature. (C, D) Normal mouse colon. Note scale bar; the magnification in D is one-half that of A and C. Scale bars in A-D are $75 \mu \mathrm{m}$. (E) Segmental dilatation in homozygous transgenic mouse 3502 with $\mathrm{Zn}^{++}$induction. Arrows indicate dilatation and attenuation of intestine wall in the colon. c-caecum (F) Low-magnification view of a transverse section of colon from animal 5305 showing relatively unaffected muscle and epithelium (arrow), severely affected muscle with abnormal epithelium (triple arrow), and transitional zones (double arrow). Bar $=2 \mathrm{~mm}$.

abnormal GI epithelium. Our results indicate, on the other hand, that transgene expression resulted in abnormal enteric nerve development, which in turn caused abnormal development of colonic smooth muscle.

Other tissues known to express GLI in normal development were not shown to be affected in the transgenic mice. A complete histologic evaluation of the central nervous system of a 3-month-old transgenic animal showed no abnormalities, and X-ray examination showed no changes in the skeleton. Blood panels and chemistries were all within normal limits, with no evidence of renal or hepatic failure that might 
TABLE 1. Number of myenteric plexuses/mm in transverse sections of colon

\begin{tabular}{lcccccc}
\hline & $\begin{array}{c}\text { Wild-type } \\
\text { CD-1 }\end{array}$ & $\begin{array}{c}\text { Healthy } \\
\text { Tg with } \\
\text { Zn }\end{array}$ & $\begin{array}{c}\text { Sick Tg } \\
\text { with Zn }\end{array}$ & $\begin{array}{c}\text { Sick Tg; } \\
\text { normal } \\
\text { wall }\end{array}$ & $\begin{array}{c}\text { Sick Tg; } \\
\text { transitional } \\
\text { wall }\end{array}$ & $\begin{array}{c}\text { Sick Tg; } \\
\text { thin } \\
\text { wall }\end{array}$ \\
\hline$n^{a}$ & 22,2 & 30,2 & 116,3 & 6,1 & 13,1 & 16,1 \\
$\begin{array}{l}\text { Number of myenteric } \\
\text { plexuses }\end{array}$ & $5.1 \pm 1.1$ & $1.9 \pm 1.3$ & $1.2 \pm 1.4$ & $4.3 \pm 1.2$ & $3.1 \pm 1.0$ & $0.3 \pm 0.6$ \\
& $*$ & $*$ & N.S. & $*$ & $*$ \\
\hline
\end{tabular}

${ }^{a}$ Density of myenteric plexuses in colon wall was determined by examining H\&E sections taken randomly for wild type, healthy transgenic ( $\mathrm{Tg}$ ), and sick $\mathrm{Tg}$, and selected as described for normal wall, transitional wall, and thin wall. Wild-type CD-1 mice were nontransgenic. Healthy $\mathrm{Tg}$ with $\mathrm{Zn}$ were $\mathrm{Tg}$ mice with induction of transgene expression but which did not show illness (small size, poor grooming, poor mobility) at the time of sacrifice. These animals, however, did display thinning of the colonic wall with a patchy distribution. Sick $\mathrm{Tg}$ with $\mathrm{Zn}$ were $\mathrm{Tg}$ mice with induction of transgene expression which did show illness (small size, poor grooming, poor mobility). $n$, number of sections examined, number of animals examined; $\mathrm{Tg}$, transgenic. ${ }^{*} p<0.0001$; N.S. $=$ not significant $($ Mann-Whitney Test $)$.

have accounted for the failure-to-thrive phenotype. On necropsy, there was no evidence of bowel perforation, peritonitis, or gross mechanical obstruction.

\section{Phenotype Severity Correlates with Increased GLI Transgene Expression}

RT-PCR was used to demonstrate expression of the transgene using primers specific for human GLI; mouse gli was not amplified in this system (Fig. 4A, B). The RT-PCR reaction was sensitive to RNase and resistant to DNase I, which indicates that the product was amplified from mRNA rather than contaminating genomic DNA. Transgenic mRNA was detected in neonatal abdomen and chest tissue as well as in adult mouse brain, liver, intestine, and lung (Fig. 4B). GLI transgene expression was not detected in skeletal muscle.

Quantitative RT-PCR studies showed that zinc induction was clearly linked to transgene expression and that the severity of the phenotype was related to the level of transgene GLI expression (Fig. 4C, D). Homozygous zinc-induced transgenic mice demonstrating the "sick" phenotype (small size, poor grooming, poor mobility) showed a 3.1-fold increase in intestinal transgene GLI RNA levels compared with healthy, noninduced mice. Healthy transgenic animals induced with zinc expressed 2.5 times the amount of intestinal transgene RNA compared with their noninduced healthy transgenic counterparts. Liver tissue from noninduced animals also showed that the quantity of transgene
RNA correlated with phenotype; sick animals demonstrated 5.1 times the transgene RNA of healthy ones. In adult mice, endogenous mouse gli expression is limited to the brain, testes, and uterus. These results show that message levels have an effect on the phenotype of the transgenic animals.

\section{DISCUSSION}

These results demonstrate that expression of human GLI CDNA in mice can lead to a distinctive phenotype involving failure to thrive, premature death, and patchy Hirschsprung-like gastrointestinal dilatation. In this model, dysregulation of GLI has a profound effect. There is dysmorphogenesis of the colon of the animals with decreased density of myenteric plexuses in the colonic wall. The gain-of-function phenotype is transgene dose-dependent, as demonstrated by RT-PCR of transgene expression levels. The phenotype of the zinc-induced homozygous mice is more extreme than that of the noninduced animals.

Sonic hedgehog $(S h h)$, one of the vertebrate homologs of Drosophila hedgehog $(h h)$, is the ligand for the patched (ptc) receptor. In flies, $h h$ regulates a negative feedback loop of $p t c$ with $c i$ in which $c i$ activates the expression of $d p p$ and $p t c$ (23). GLI is the vertebrate homolog of $c i$, and $B m p-2 / 4$ are the vertebrate homologs of $d p p$. Dysregulation of $d p p$ in Drosophila disrupts normal midgut constriction $(21,24)$, and dysregulation 

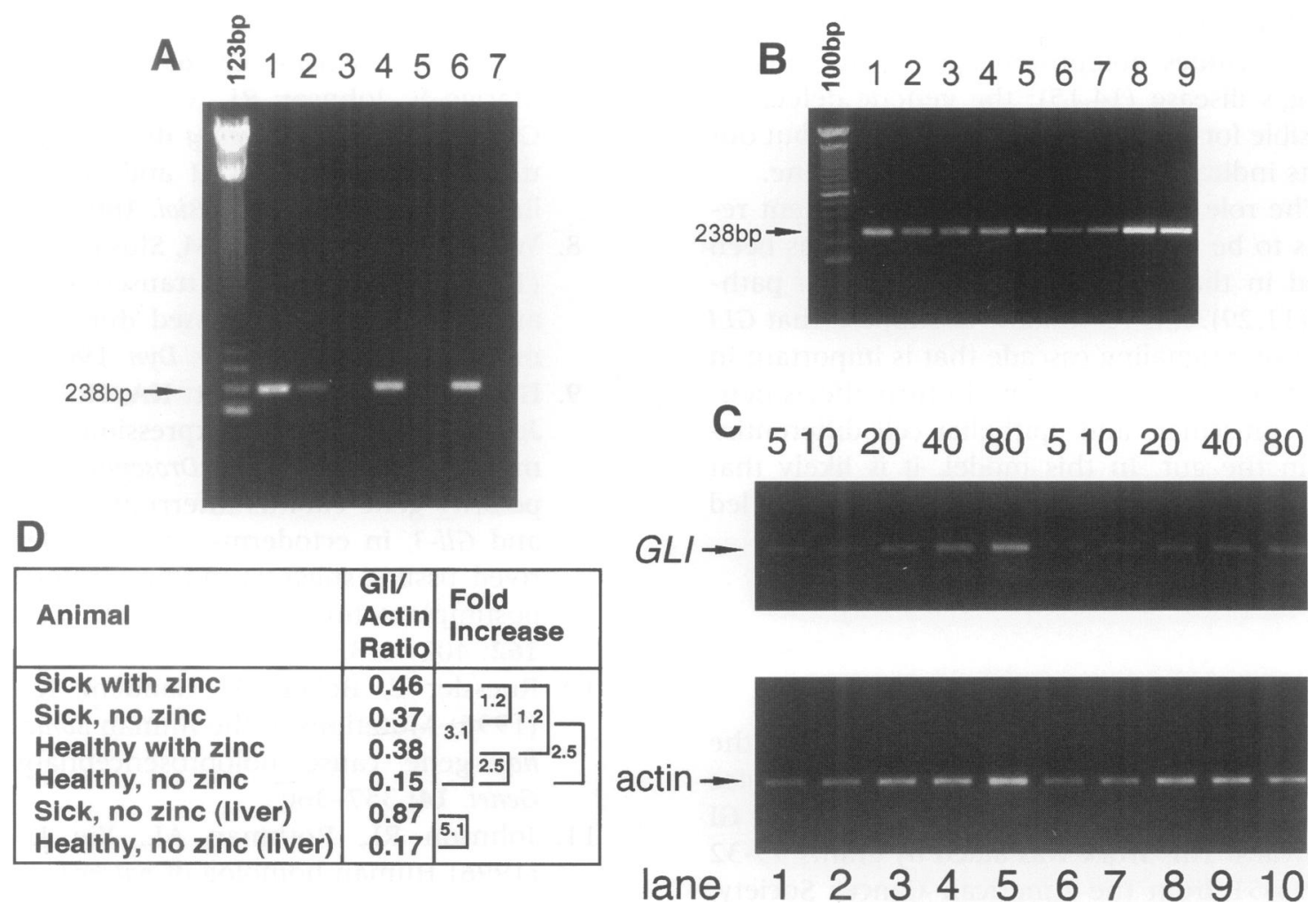

\section{FIG. 4. Transgene expression detected by RT-PCR}

DNase I-treated RNA was used for all reactions, and the predicted $238 \mathrm{bp}$ band is shown. (A) Low concentrations of RNase reduced the amplified transgene produced by RT-PCR. Absence of reverse transcriptase results in no amplification, indicating that DNase I treatment eliminated all of the DNA and that the amplified product results from RNA-derived cDNA generated by the reverse transcriptase. Samples came from intestine of homozygous transgenic animals 4402 (lanes 1-3), 4302 (lanes 4, 5), and 4503 (lanes 6, 7). Lanes 1, 4, and 6: reaction with reverse transcription; lane 2: reaction with reverse transcription plus pretreatment with low concentration of RNase; lanes 3, 5, and 7: reaction without reverse transcription. (B) Multiple-tissue expression of transgene. Lanes 1-4: brain, intestine, liver, lung RNA from animal 4402; lane 5: liver from animal 4302; lane 6: liver RNA from animal 4503; lane 7: intestinal RNA from animal 4503; lane 8: abdominal and chest RNA in day l newborn animal 4301; lane 9: abdominal and chest RNA in day 2 newborn animal 4501. (C) Quantitative RT-PCR from intestinal RNA from animals 5308 and 4603. Lanes 1-5: actin and gli expression in a sick, zinc-induced transgenic animal (5308); lanes 6-10: actin and gli expression in a healthy, $\mathrm{Zn}^{++}$-induced transgenic animal (4603). Lanes 1 and 6: 5 ng RNA; lanes 2 and 7: $10 \mathrm{ng}$ RNA; lanes 3 and 8: $20 \mathrm{ng}$ RNA; lanes 4 and 9: $40 \mathrm{ng}$ RNA; lanes 5 and 10: $80 \mathrm{ng}$ of RNA. Actin expression was linear from 5 to $20 \mathrm{ng}$, and GLI expression was linear from 5 to $40 \mathrm{ng}$ of intestinal RNA. (D) Quantification of relative RNA expression. The ratio of GLI/actin band intensities from gels as those shown in C were compared using NIH Image after digital scanning.

of Shh causes ectopic expression of $B m p-4$ and Hoxd genes in chick hindgut mesoderm (25). Mouse gli is highly expressed in the mesodermal layer of normal GI tract from E13 until birth $(8,26)$. Thus, the essential elements of a mesoderm-epithelial signaling network in the GI tract involving $S h h, p t c, g l i$, and Bmp-4 are conserved from Drosophila to vertebrates. Therefore, ectopic expression of $G L I$ would be expected to disrupt the pathway and result in abnormal gut development; this is precisely the result obtained in the present study. A similar but more posterior phenotype to the one presented here is obtained when Hoxd13 is knocked out in mice (27).

In humans, disruption of Shh results in holoprosencephaly, a very serious dysmorphogenic syndrome with numerous midline defects and axial skeletal abnormalities (10). These patterning defects, including cyclopia, are recapitulated in mice with null mutations of Shh (28). Deletions in the 3' end of GLI3 in humans results in Pallister-Hall syndrome, manifesting hypothalamic hamartoma, hypopituitarism, polydactyly, imperforate anus, and renal and lung anomalies 
(13). There is a variant of Pallister Hall syndrome which includes holoprosencephaly and Hirschsprung's disease $(14,15)$; the genetic defect responsible for this variation is not known, but our results indicate that $G L I$ is a candidate gene.

The role of GLI in GI tract development remains to be established, but since GLI has been placed in the vertebrate hedgehog/patched pathway $(11,29)$, it is reasonable to suppose that GLI is part of a signaling cascade that is important in mesoderm development and in turn affects neuronal, muscular, and epithelial cell differentiation in the gut. In this model, it is likely that impairment of enteric neuronal development led to the Hirschsprung-like phenotype.

\section{ACKNOWLEDGMENTS}

We thank Dr. M. DalCanto for performing the CNS histologic evaluation of the transgenic mice and Dr. P. Chou for histologic evaluation of GI tract walls. This work was aided by grants 93-32 and 94-51 from the American Cancer Society, Illinois Division, Inc. and was supported in part by Public Health Service grant CA64395 from the National Cancer Institute and HD28992 from the National Institute of Child Health and Human Development.

\section{REFERENCES}

1. Kinzler KW, Bigner SH, Bigner DD, et al. (1987) Identification of an amplified, highly expressed gene in a human glioma. Science 236(4797): 70-73.

2. Ruppert JM, Vogelstein B, Kinzler K. (1991) The zinc finger protein GLI transforms primary cells in cooperation with adenovirus E1A. Mol. Cell. Biol. 11: 1724-1728.

3. Kinzler KW, Ruppert JM, Bigner SH, Vogelstein B. (1988) The GLI gene is a member of the Kruppel family of zinc finger proteins. Nature 332(6162): 371-374.

4. Ruppert JM, Kinzler KW, Wong AJ, et al. (1988) The GLI-Kruppel family of human genes. Mol. Cell. Biol. 8: 3104-3113.

5. Orenic TV, Slusarski DC, Kroll KL, Holmgren RA (1990) Cloning and characterization of the segment polarity gene cubitus interruptus dominant of Drosophila. Genes Dev. 4: 1053-1067.

6. Hunter CP, Wood WB. (1990) The tra-1 gene determines sexual phenotype cell-autonomously in C. elegans. Cell 63: 1193-1204.

7. Marigo V, Johnson RL, Vortkamp A, Tabin CJ. (1996) Sonic Hedgehog differentially regulates expression of GLI and GLI3 during limb development. Dev. Biol. 180: 273-283.

8. Walterhouse D, Ahmed M, Slusarski D, et al. (1993) gli, a zinc finger transcription factor and oncogene, is expressed during normal mouse development. Dev. Dyn. 196: 91-102.

9. Hui CC, Slusarski D, Platt KA, Holmgren R, Joyner AL. (1994) Expression of three mouse homologs of the Drosophilia segment polarity gene cubitus interruptus, Gli, Gli-2, and Gli-3, in ectoderm- and mesoderm-derived tissues suggests multiple roles during postimplantation development. Dev. Biol. 162: 402-413.

10. Roessler E, Belloni E, Gaudenz K, et al. (1996) Mutations in the human Sonic Hedgehog gene cause holoprosencephaly. Nat. Genet. 14: 357-360.

11. Johnson RL, Rothman AL, Xie J, et al. (1996) Human homolog of patched, a candidate gene for the basal cell nevus syndrome. Science 272(5268): 1668-1671.

12. Vortkamp A, Gessler M, Grzeschik KH. (1991) Gli3 zinc-finger gene interrupted by translocation in Greig syndrome families. Nature 352: 539-540.

13. Kang S, Graham JM Jr., Olney AH, Biesecker LG. (1997) GLI3 frameshift mutations cause autosomal dominant PallisterHall syndrome. Nat. Genet. 15: 266-268.

14. Verloes A, Gillerot Y, Langhendries JP, Fryns JP, Koulischer L. (1992) Variability versus heterogeneity in syndromal hypothalamic hamartoblastoma and related disorders: Review and delineation of the cerebro-acrovisceral early lethality (CAVE) multiplex syndrome. Am. J. Med. Genet. 43: 669-677.

15. Donnai D, Burn J, Hughes H. (1987) SmithLemli-Opitz syndromes: Do they include the Pallister-Hall syndrome? Am. J. Med. Genet. 28: 741-743.

16. Roberts WM, Douglass EC, Peiper SC, Houghton PJ, Look AT. (1989) Amplification of the gli gene in childhood sarcomas. Cancer Res. 49: 5407-5413.

17. Salgaller M, Pearl D, Stephens R. (1991) In situ hybridization with single-stranded RNA probes to demonstrate infrequently elevated gli mRNA and no increased ras mRNA levels in meningiomas and astrocytomas. Cancer Lett. 57: 243-253. 
18. Palmiter RD, Norstedt G, Gelinas RE, Hammer RE, Brinster RL. (1983) Metallothionein-human GH fusion genes stimulate growth of mice. Science 222(4625): 809-814.

19. Cunha GR, Battle E, Young P, et al. (1992) Role of epithelial-mesenchymal interactions in the differentiation and spatial organization of visceral smooth muscle. Epithelial Cell Biol. 1: 76-83.

20. Pavlova A, Boutin E, Cunha G, Sassoon D. (1994) Msxl (Hox-7.1) in the adult mouse uterus: Cellular interactions underlying regulation of expression. Development 120: 335 345.

21. Panganiban GEF, Reuter R, Scott MP, Hoffmann FM. (1990) A Drosophila growth factor homolog, decapentaplegic, regulates homeotic gene expression within and across germ layers during midgut morphogenesis. Development 110: 1041-1050.

22. Immerglück $K$, Lawrence $P A$, Bienz $M$. (1990) Induction across germ layers in Drosophila mediated by a genetic cascade. Cell 62: 261-268.

23. Hepker J, Wang QT, Cynthia MK, Holmgren R, Orenic TV. (1997) Drosophila cubitus interruptus forms a negative feedback loop with patched and regulates expression of Hedgehog target genes. Development 124: 549558.

24. Staehling-Hampton K, Hoffmann FM.
(1994) Ectopic decapentaplegic in the Drosophila midgut alters the expression of five homeotic genes, $d p p$, and wingless, causing specific morphological defects. Dev. Biol. 164: 502-512.

25. Roberts DJ, Johnson RL, Burke AC, Nelson CE, Morgan BA, Tabin C. (1995) Sonic Hedgehog is an endodermal signal inducing $\mathrm{Bmp}-4$ and Hox genes during induction and regionalization of the chick hindgut. Development 121: 3163-3174.

26. Platt KA, Michaud J, Joyner AL. (1997) Expression of the mouse Gli and Ptc genes is adjacent to embryonic sources of Hedgehog signals suggesting a conservation of pathways between flies and mice. Mech. Dev. 62: 121-135.

27. Kondo T, Dolle P, Zakany J, Duboule D. (1996) Function of posterior HoxD genes in the morphogenesis of the anal sphincter. $D e$ velopment 122: 2651-2659.

28. Chiang $C$, Litingtung $Y$, Lee $E$, et al. (1996) Cyclopia and defective axial patterning in mice lacking Sonic Hedgehog gene function. Nature 382(6599): 407-413.

29. Vortkamp A, Lee K, Lanske B, Segre G, Kronenberg HM, Tabin CJ. (1996) Regulation of rate of cartilage differentiation by Indian hedgehog and PTH-related protein. Science 273(5275): 613-622.

Communicated by A. J. Levine. Accepted October 20, 1997. 